Оптимальный по скорости закон двухкомпонентных колебаний вибрационнных транспортных устройств с электромагнитным приводом

И.И. Врублевский

Рассмотрен процесс скоростного вибрационного транспортирования при гармонических продольных колебаниях и нормальных колебаниях с кусочно-постоянным ускорением, которые являются оптимальными по скорости для устройств с электромагнитным приводом. Выведена формула зависимости скорости вибротранспортирования от безразмерных параметров. Рассмотрена аппроксимачия оптимальных нормальных колебаний полигармоническими колебаниями. Приведены графики зависимости коэффициента скорости от безразмерных параметров, что позволяет определять значения скорости вибротранспортирования при заданных значениях амплитуды и частоты колебаний и необходимых углах подъёма.

Ключевые слова: вибрационное транспортирование, двухкомпонентные колебания

\title{
Optimal by Velocity Two-Component Oscillation Law of Vibratory Conveying Devices with the Electromagnetic Drive \\ I. Vrublevskyi
}

The vibratory conveying with harmonic longitudinal oscillations and normal oscillations with piecewise constant acceleration is investigated. Such oscillations provide the maximal conveying velocity in the vibratory devices with the electromagnetic drive. Formula of dependence of the conveying velocity on the dimensionless parameters is derived. Approximation of optimal normal oscillations by the polyharmonic oscillations is considered. Graphs of dependence of the velocity coefficient on the dimensionless parameters allow to determine the conveying velocity under the given amplitude and frequency of oscillations and track angle.

Key words: vibratory conveying, two-component oscillations.

\section{УДК 519.876 .5}

\author{
B.І. Грабчак ${ }^{1}$, В.М. Супрун ${ }^{2}$, Ю.С. Бистрик ${ }^{2}$ \\ ${ }^{1}$ Академія сухопутних військ, Львів \\ ${ }^{2}$ Сумський державний університет, Суми
}

\section{МАТЕМАТИЧНА МОДЕЛЬ ОПТИМАЛЬНОГО РОЗПОДІЛУ ЗАСОБІВ УРАЖЕННЯ}

У статті розроблена математична модель оптимального розподілу засобів ураження по иілях противника. Обгрунтовано метод знаходження оптимального розв'язку задачі двостороннього бою між протидіючими неоднорідними угрупованнями на основі метода максимального елемента (градієнтний метод), наведено алгоритм, за допомогою якого розраховані показники ефективності ураження иілей противника. Розглянутий практичний приклад функціонування моделі оптимального розподілу засобів ураження.

Ключові слова: математична модель, оптимальні методи управління, метод максимального елемента, показники ефективності ураження.

\section{Ветуп}

Постановка проблеми в загальному вигляді та аналіз літератури. Розвиток математичних методів дозволяє розв'язувати принципово нові задачі у військовій справі, які характерні складними залежностями, великою розмірністю і необхідністю враховувати велику кількість факторів. Особливо це стосується тих задач, у яких необхідно знаходити оптимальне рішення. У цьому випадку приходять до математичного моделювання, оскільки за допомогою математичної моделі можна за відомими вхідними даними отримати нові, раніше невідомі дані про досліджуваний об'єкт $[1,2]$.

Практичні задачі військової справи, які описуються математичними методами, можна розбити на дві групи
$[2,3]$. До першої відносяться задачі визначення оптимальних методів управління технічними системами, знаходження оптимальних варіантів бойових дій, організація ремонту озброєння та інші. Друга група включає задачі, пов'язані з визначенням оптимальних характеристик перспективних систем озброєння i військової техніки, які розробляються. До класу таких задач відносяться так звані задачі розподілу, які зводяться до того, що необхідно знайти такий розподіл ресурсів за операціями, при якому або мінімізуються загальні витрати, або максимізується деяка міра ефективності [2, 3].

При математичній постановці задачі оптимізації використовується поняття критерію оптимальності 
як показника, екстремальне значення якого характеризує максимально можливу ефективність системи $[4,5]$.

Серед математичних методів оптимізації важливе місце займає метод динамічного програмування [6], який застосовується для розв'язання найрізноманітніших військових, технічних і економічних задач.

Однією 3 таких задач, яка відіграє суттєву роль при плануванні і управлінні бойовими діями, є задача оптимального розподілу засобів ураження при веденні двостороннього бою між протидіючими неоднорідними угрупованнями.

Метою статті $\epsilon$ розв'язок задачі оптимального розподілу засобів ураження поміж різними цілями за допомогою так званого метода максимального елемента, який відноситься до градієнтних методів; побудова математичної моделі оптимального розподілу засобів ураження по цілях противника; обгрунтування методу знаходження оптимального розв' язку задачі і розробка алгоритму, за допомогою якого можливо знайти шукані показники ефективності ураження цілей противника.

\section{Основна частина}

1. Постановка задачі. Противник підрозділами 2 мбр веде наступ (рис. 1) із завданням прорвати оборону 1 мбр і оволодіти районом оборони 1 мб.

1 мб бригади обороняє район оборони батальйону iз завданням нанести противнику максимальних втрат, не допустити прориву на даному напрямку і втримати займаний район. 2/3 БрАГ підтримує дії 1 мб; 1/3 БрАГ знаходиться у безпосередньому підпорядкуванні командира 4 мбр.

Вогневі завдання 2/3 БрАГ: уразити цілі - 212, 301, А51 і бути в готовності до ураження інших цілей. Вогневі завдання 1/3 БрАГ: уразити цілі - M21, 211, 302 і бути в готовності до ураження інших цілей.

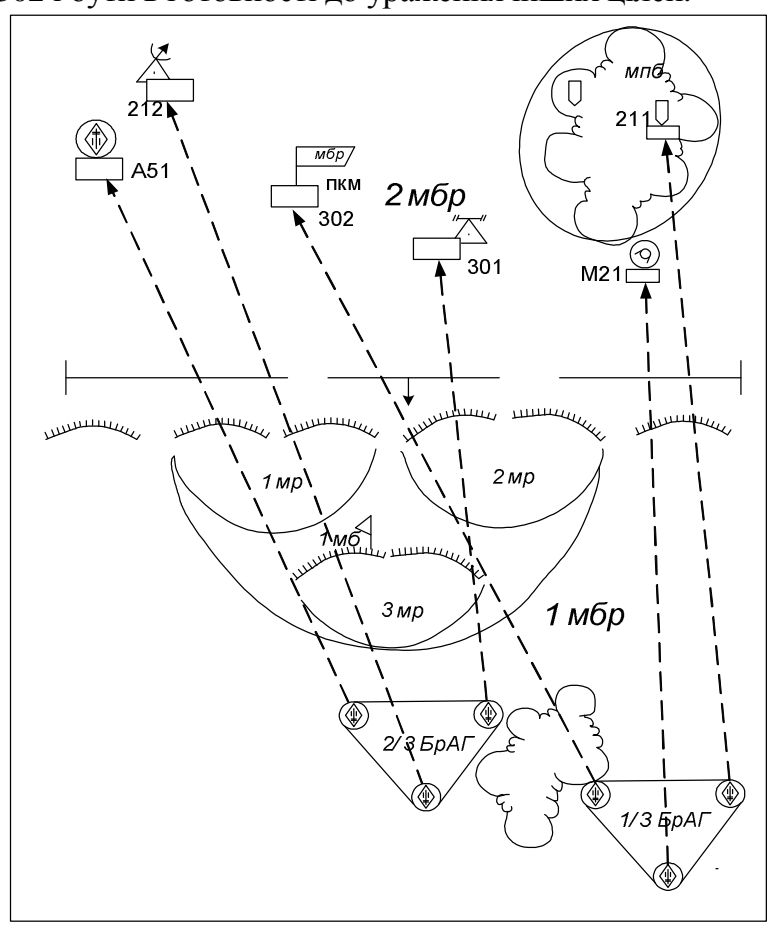

Puc. 1. Схема протидії угруповань А і В
Виходячи з тактичної обстановки постає задача побудови математичної моделі, яка описує процес бойових дій між протидіючими угрупованнями:

- угруповання А - противник, який має у своєму складі відповідні засоби і сили, застосування яких веде до поставленої мети;

- угруповання В - сили району оборони i засоби ураження, завдання яких полягає в нанесенні противнику максимальних втрат силами $2 / 3$ БрАГ і 1/3 БрАГ.

В якості показника ефективності бойових дій приймемо максимум математичного сподівання втрат, що завдається противнику.

2. Математична модель оптимального розподілу засобів ураження по цілях противника. Позначимо через $N$ - число неоднорідних засобів ураження, яке має у своєму складі угруповання В, через $m$ - число цілей угруповання А, що підлягають ураженню. Нехай задана важливість $A_{i}(i=1,2 \ldots m)$ кожної цілі і ймовірності $P_{j i}$ ураження $i$-ї цілі $j$-ю гарматою у вигляді матриці

$$
P=\left(\begin{array}{cccccc}
P_{11} & P_{12} & \ldots & P_{1 i} & \ldots & P_{1 m} \\
P_{21} & P_{22} & \ldots & P_{2 i} & \ldots & P_{2 m} \\
\vdots & & & & & \vdots \\
P_{j 1} & P_{j 2} & \ldots & P_{j i} & \ldots & P_{j m} \\
\vdots & & & & & \vdots \\
P_{N 1} & P_{N 2} & \ldots & P_{N j} & \ldots & P_{N m}
\end{array}\right) .
$$

Розглянемо випадкову подію $A_{i}(i=1,2 . . m)$, яка полягає у тому, що на $i$-ту ціль направлені деякі з $N$ гармат і вона уражена, тобто має місце хоча б одна iз випадкових подій $A_{1 i}, A_{2 i}, \ldots, A_{N i}$ - ціль уражена відповідно 1-ю, 2-ю,.., $N$-ю гарматами. Очевидно, що події $A_{i}$ ( $i$-та ціль уражена хоча 6 одною із гармат) та $\overline{A_{1 i}} \overline{A_{2 i}} \ldots \overline{A_{N i}}$ (жодна із гармат не уразила $i$-ту ціль) - протилежні, тоді

$$
P\left(A_{i}\right)+P\left(\overline{A_{1 i}} \overline{A_{2 i}} \ldots \overline{A_{N i}}\right)=1,
$$

звідки, користуючись теоремою множення для взаємно незалежних подій [5, 6], одержуємо

$$
P\left(A_{i}\right)=1-P\left(\overline{A_{1 i}} \overline{A_{2 i}} \ldots \overline{A_{N i}}\right)=1-\prod_{j=1}^{N} P\left(\overline{A_{j i}}\right)
$$

або, остаточно, поклавши $p_{i}=P\left(A_{i}\right), p_{j i}=P\left(A_{j i}\right)$, маємо

$$
p_{i}=1-\prod_{j=1}^{N}\left(1-p_{j i}\right)^{x_{j i}},
$$

де $x_{j i}=1$ для тих $j$-х засобів, які направлені в $i$-ту ціль $\mathrm{i}$, таким чином, відповідні їм множники $\left(1-p_{j i}\right)$ 
присутні в добуткові у першому степені; $x_{j}=0$ для тих $j$-х засобів, які не направлені в ціль, і відповідні їм множники $\left(1-p_{j i}\right)$ дорівнюють одиниці. Таким чином, $x_{j i}-$ кількість засобів, що виділяються для дії по $i$-й цілі $j$-им засобом. Тоді $[4,7]$ математичне сподівання випадкової величини $X$ - числа втрат, що будуть завдані противнику, визначимо за формулою

$$
\Phi(X)=\sum_{i=1}^{m} A_{i} p_{i}
$$

або 3 урахуванням (4) і того, що максимум втрат, наприклад, розподіляється по $S$ цілях із $m$, отримуємо математичну модель, яка описує протидію угруповань А і В

$$
\Phi(X)=\sum_{i=1}^{S} A_{i}\left[1-\prod_{j=1}^{N}\left(1-p_{j i}\right)^{x_{j i}}\right]
$$

Отже, математичне формулювання поставленої задачі зводиться до наступного твердження: необхідно знайти такий розподіл, тобто вектор $X_{0}=\left\{x_{j i}^{0}\right\}_{m}$, при якому досягається максимум функції (6) при лінійному обмеженні на його компоненти

$$
\sum_{i=1}^{S} \sum_{j=1}^{N} x_{j i} \leq N
$$

і додаткових умовах:

$$
\left\{\begin{array}{l}
x_{j i} \in\{0,1, \ldots, N\} \\
0 \leq\left(q_{j i}=1-p_{j i}\right) \leq 1, \\
A_{i}>0, \overline{1, S}, j=\overline{1, N} \\
i=
\end{array}\right.
$$

3. Обгрунтування методу знаходження оптимального розв'язку задачі. В даній задачі потрібно скласти оптимальний план розподілу засобів за цілями, тобто із формули (6) видно, що треба розглянути всі комбінації розподілів ј-го засобу по iй цілі і визначити, яка із цих комбінацій буде надавати цільовій функції максимальне значення.

В основу методу знаходження оптимального розв'язку $[4,8]$ задачі буде покладено метод максимального елемента [6,9-11], суть якого полягає в наступному.

На довільному кроці процесу розподіляється тільки одна одиниця дискретного ресурсу. На формальній мові це означає, що на $t$-му кроці процесу $(t=1, \ldots, T)$ одиничний приріст $\Delta=1$ надається тільки одній $\left(j_{t}, i_{t}\right)$-й компоненті шуканої оптимальної матриці $X_{0}=\left\{x_{j i}^{0}\right\}$. Таким чином, після кінцевого числа кроків
$t=T$, рівного числу одиниць ресурсу $(N)$, увесь ресурс буде розподіленим, тобто отримано оптимальне рішення поставленої задачі.

Як видно, алгоритм побудований на послідовному розподіленні засобів по одному на кожному кроці процесу, у відповідності з максимальним приростом цільової функції. Отримаємо вираз для обрахунку цільової функції $\Phi_{t}^{+}$на довільному кроці процесу.

Нехай до моменту призначення $t$-го засобу кожний об'єкт вже уражений з певною ймовірністю

$$
P_{j i}^{(t-1)}=1-\prod_{j=1}^{N}\left(1-p_{j i}\right)^{x} \text { aб } \text { або } P_{j i}^{(t-1)}=1-Q_{j i}^{(t-1)}
$$

за рахунок попереднього розподілення $(t-1)$ певних засобів по деяких точках прицілювання. Сумарні очікувані втрати будуть становити

$$
\Phi_{t-1}^{+}=\sum_{i=1}^{S} A_{i} P_{j i}^{(t-1)}
$$

За рахунок пробного призначення (пробні призначення для всіх $\left(j_{t}, i_{t}\right)$ необхідні для того, щоб виявити максимальний елемент вектора приросту) ще одного $j_{t}$-го засобу по $i_{t}$-й точці прицілювання на $t$-му кроці процесу функція $\Phi(X)$ прийме значення

$$
\Phi_{t}^{+}=\sum_{i \neq i_{t}}^{S} A_{i} P_{j \neq j_{t}, i}^{(t-1)}+A_{i_{t}}\left(1-Q_{j_{t} i_{t}}^{(t-1)} q_{j_{t} i_{t}}\right) .
$$

Знайдемо приріст функції $\Phi_{t}^{+}$, який отримується в даному випадку на $t$-му кроці процесу

$$
\Delta_{j_{t}, i_{t}}^{+}=\Phi_{t}^{+}-\Phi_{t-1}^{+}=A_{i_{t}} Q_{j_{t} i_{t}}^{(t-1)} p_{j_{t} i_{t}}
$$

Використовуючи позначення

$$
A_{i_{t}}^{(t-1)}=A_{i_{t}} Q_{j_{t} i_{t}}^{(t-1)}
$$

запишемо приріст $\Delta_{j_{t} i_{t}}^{+}$в кінцевому вигляді

$$
\Delta_{j_{t} i_{t}}^{+}=A_{i_{t}}^{(t-1)} p_{j_{t} i_{t}}, j_{t}=\overline{1, N}, i_{t}=\overline{1, S}
$$

4. Алгоритм оптимального розв'язку задачі. Використовуючи попередні міркування, алгоритм оптимізації тепер може бути записаний наступним чином.

1. Знайти компоненти матриці $\Delta_{j_{t} i_{t}}^{+}$для чергового кроку процесу за формулою

$$
\Delta_{j_{t} i_{t}}^{+}=A_{i_{t}}^{(t-1)} p_{j_{t} i_{t}}, j_{t}=\overline{1, N}, i_{t}=\overline{1, S},
$$

при цьому для $t=1$ маємо $A_{i_{t}}^{(0)}=A_{i_{t}}$. 
2. Призначити одиничний засіб по $l=l_{t}$-й точці прицілювання, для якої виконується умова

$$
\Delta_{j_{t} i_{t}}^{+}=\max _{\substack{1 \leq j_{t} \leq N \\ 1 \leq i_{t} \leq S}} \Delta_{j_{t} i_{t}}^{+}
$$

3. Знайти поточну кількість засобів, що назначені $3 j_{t}$-го засобу по $i_{t}$-й точці прицілювання:

$x_{j_{t} i_{t}}^{(t)}=\left\{\begin{array}{l}x_{j_{t} i_{t}}^{(t-1)}, \text { якщзо } j_{t} \text { засібненаправлений на } i_{t} \text { ціль, } \\ x_{j_{t} i_{t}}^{(t-1)}+1, \text { якщуо } j_{t} \text { засіб направлений на } i_{t} \text { цุiль, }\end{array}\right.$ при цьому

$$
x_{j_{t} i_{t}}^{(0)}=0
$$

4. Перерахувати важливість (вагу) об'єктів за формулою

$$
A_{i_{t}}^{(t)}=A_{i_{t}}^{(t-1)} q_{j_{t} i_{t}}
$$

5. Знайти поточне значення втрат

$$
\Phi_{t}^{+}=\Phi_{t-1}^{+}+\Delta_{l_{t}, i_{t}}^{+}, \Phi_{0}=0, t:=t+1 .
$$

6. Перевірити умову $t \leq N$ : так - перейти до пункту 1, ні - перейти до пункту 7.

7. Показати результат

$$
\Phi\left(X_{0}\right)=\Phi_{N}^{+}, \quad\left\{x_{j_{t} i_{t}}^{0}\right\}=\left\{x_{j_{t} i_{t}}^{(N)}\right\}
$$

і закінчити обчислення.

Покажемо, що запропонований алгоритм $\epsilon$ оптимальним і забезпечує точне рішення задачі.

Розглянемо роботу алгоритму, починаючи 3 $t=1$-го кроку процесу. Для простоти розглянемо випадок, коли $X=\left\{x_{l}\right\}$ є вектором, у випадку матриці аналіз оптимальності алгоритму є аналогічним.

Маємо вектор $\left\{\Delta_{l}^{+}\right\}_{m}, \quad$ компоненти якого (прирости) пронумеровані в порядку зменшення величин

$$
\Delta_{1}^{+} \geq \Delta_{2}^{+} \geq \ldots \geq \Delta_{l}^{+} \geq \ldots \geq \Delta_{n}^{+} .
$$

Згідно з алгоритмом при даній нумерації засіб буде назначатися спочатку на перший об'єкт $(l=1)$. Буде назначена така їх кількість $x_{1}=k$, при якій уже наступний $(k+1)$-й засіб не забезпечує об'єкту $l=1$ найбільший приріст, таким чином, умова (14) порушується, тобто:

$$
\begin{gathered}
\left.\Delta_{1}^{+}\right|_{x_{1}=k} \geq \Delta_{2}^{+} \geq \ldots \geq \Delta_{l}^{+} \geq \ldots \geq \Delta_{n}^{+}, \\
\left.\Delta_{1}^{+}\right|_{x_{1}=k+1}<\Delta_{2}^{+} \geq \ldots \geq \Delta_{l}^{+} \geq \ldots \geq \Delta_{n}^{+} .
\end{gathered}
$$

Тоді наступний $(k+1)$-й засіб буде назначено на об'єкт $l=2$, і далі призначення будуть чергуватися між першими двома об'єктами доти, поки приріст на третьому об'єкті не перевищить приріст на кожному iз перших двох. Наступний засіб у таких умовах згідно 3 алгоритмом буде назначатися на третій об'єкт і т.д. до розподілення всіх $m$-х засобів.
Така процедура приводить до максимального зрівнювання поточних приростів $\Delta_{l}^{+}$на деякій сукупності перших $r$ об'єктів з найменшими порядковими номерами, що відповідають послідовності (14). Якщо середнє арифметичне значення приростів $\Delta_{l}^{+}$для перших $r$ об'єктів позначити через $\lambda$, то можна записати

$$
\left.\left.\left.\lambda \approx \Delta_{1}^{+}\right|_{x_{1}=k_{1}} \approx \Delta_{2}^{+}\right|_{x_{2}=k_{2}} \approx \ldots \approx \Delta_{r}^{+}\right|_{x_{r}=k_{r}} \geq \Delta_{r+1}^{+} \geq \ldots \geq \Delta_{m}^{+},
$$

де вектор $\left\{x_{l}\right\}_{r}$ задовольняє умову: $\sum_{l=1}^{r} x_{l} \leq N$.

Зміст виразу (17) полягає в тому, що приріст $\Delta_{l}^{+}$, отримуваний за рахунок $x_{l}$-го засобу, приблизно рівний для перших $r$ об'єктів і не менший, ніж приріст від однієї одиниці засобів для кожного із інших $(l>r)$ об'єктів, тобто

$$
\Delta_{l}^{+}=\left\{\begin{array}{l}
\approx \lambda, \text { якщео } x_{l}>0(l \leq r), \\
\leq \lambda, \text { якщео } x_{l}=0(l>r) .
\end{array}\right.
$$

Але величина $\Delta_{l}^{+}=\Phi_{t}^{+}-\Phi_{t-1}^{+}$, по суті, $є$ різницевим аналогом частинної похідної $\frac{\partial \Phi(X)}{\partial x_{l}}$ при одиничному прирості змінної ( $\Delta x_{l}=1$ ). Відповідно замість (18) можна записати

$$
\frac{\partial \Phi(X)}{\partial x_{l}}=\left\{\begin{array}{c}
\frac{\Delta \Phi\left(x_{l}\right)}{\Delta x_{l}} \approx \lambda \text { для } l \leq r, \\
\frac{\Delta \Phi\left(x_{l}\right)}{\Delta x_{l}} \leq \lambda \text { для } l>r .
\end{array}\right.
$$

Умову (19) можна розглядати як дискретний варіант необхідних умов Лагранжа для екстремуму $[5,9]$.

Дійсно, відмовимося тимчасово від умови дискретності та невід'ємності змінних $x_{j}$. Тоді задача (6-8) може бути вирішена за допомогою множників Лагранжа. Функція Лагранжа [12] буде мати вигляд

$$
\Psi(X)=\Phi(X)-\delta\left(\sum_{j=1}^{m} x_{j}-N\right)
$$

де $\delta$ - множник Лагранжа.

Необхідні умови екстремуму

$$
\frac{\partial \Psi}{\partial x_{j}}=\frac{\partial \Phi\left(x_{j}\right)}{\partial x_{j}}-\delta, \quad j=\overline{1, m}
$$

Припустимо, що при цих умовах змінні, починаючи з $x_{r+1}$, від'ємні. Для того, щоб зберігати умову невід'ємності, потрібно прийняти ці змінні рівними нулю, тоді умова (21) прийме вигляд

$$
\left\{\begin{array}{l}
\frac{\partial \Phi\left(x_{j}\right)}{\partial x_{j}}=\delta, \quad \text { для } j \leq r\left(x_{j} \neq 0\right), \\
\frac{\partial \Phi\left(x_{j}\right)}{\partial x_{j}} \leq \delta, \text { для } j>r\left(x_{j}=0\right) .
\end{array}\right.
$$


Оскільки функція $\Phi\left(x_{j}\right)$ випукла вгору по кожній змінній (це забезпечує єдність рішення), то умова (22) являє собою і достатню умову максимуму. Зменшуючи крок дискретності (різниця між двома допустимими суміжними значеннями змінної $x_{j}$ ) до нуля умови (19) i умови (22) збігатимуться з точністю до позначення, що вказує нам на оптимальність запропонованого алгоритму.

Відмітимо, що на практиці такого збігу бути не може, оскільки тоді алгоритм стане мати нескінченну кількість кроків. “Неперервний” варіант задачі (6-8) може бути вирішений за допомогою даного алгоритму наближено, з будь-яким ступенем точності, що забезпечується кроком дискретності. Покращення збігу можна досягти за допомогою зменшення кроку дискретності в ході оптимізації.

Слід зазначити, що умови (17), а значить, і (19), виконуються в ході всієї оптимізації, тому і всі проміжні рішення також є оптимальними.

5. Конкретизація математичної моделі оптимального розподілу засобів ураження по цілях у відповідності з поставленим завданням.

3 умови задачі отримуємо такі вихідні дані:

a) ураженню підлягають $m=6$ цілей угруповання А: 212, 301, А51, 302, 211, М21;

б) уражаючими вогневими засобами угруповання Б є артилерійські підрозділи 2/3 БрАГ і 1/3 БрАГ, які можуть виконувати поставлене завдання дивізіоном, двома батареями або однією батареєю. Таким чином, будемо вважати, що угруповання Б має у своєму складі $N=6$ засобів ураження;

в) 3 точки зору командування угрупованням Б на даний момент часу найбільш важливими є цілі 302, А51 та 301 (тобто $S=3$ ), яким надаються відповідно коефіцієнти важливості: 50\%, 30\% та $20 \%$.

Завдання - розподілити засоби ураження угруповання Б таким чином, щоб математичне сподівання втрат противника було максимальним.

Таким чином, конкретизована задача $[7,13]$ оптимального цілерозподілу засобів ураження звелася до знаходження набору компонент матриці $X_{0}=\left\{x_{j i}^{0}\right\}_{m=6}$ при лінійному обмеженні на їі компоненти

$$
\sum_{i=1}^{3} \sum_{j=1}^{6} x_{j i} \leq 6
$$

і додаткових умовах

$$
\left\{\begin{array}{l}
x_{j i} \in\{0,1, \ldots, 6\}, \\
0 \leq\left(q_{j i}=1-p_{j i}\right) \leq 1, \\
A_{i}>0, \\
i=\overline{1,3}, j=\overline{1,6}
\end{array}\right.
$$

та надають максимального значення нелінійній функції

$$
\Phi(X)=\sum_{i=1}^{3} A_{i}\left[1-\prod_{j=1}^{6} q_{j i}{ }^{x_{j i}}\right] .
$$

6. Розрахунок ступеня ураження цілей противника. Для розрахунку ступеня ураження цілей противника скористаємося розробленим алгоритмом (рис. 2).

В якості елементів матриці (1) взято математичне сподівання відносного числа уражених окремих цілей зі складу групової або ймовірність ураження цілі. Дані для розрахунку ступеня ураження відповідних цілей обираємо 3 [7, 14, 15] для артилерійської системи 152-мм СГ2С $3 \mathrm{M}$ снаряд ОФ-540.

Для ілюстрації наведемо приклад розрахунку одного 3 елементів в матриці (1). 3 цією метою сформулюємо наступну задачу: для ураження відкрито розташованої РЛС артилерійських підрозділів залучається дивізіон 152-мм СГ2С 3 М. Дальність стрільби $12 \kappa м$. Визначення установок для стрільби на ураження здійснюється на основі повної підготовки [15]. Визначити ефективність ураження цілі.

Розв'язок. 3 умови прикладу маємо: ціль окрема, неспостережна. Основний елемент, що підлягає ураженню, - антена. Вражаючий фактор - осколки. Подія ураження цілі - виведення РЛС зі стану боєздатності.

Згідно з даними $[7,14,15]$ вибираємо вхідні величини: зведена зона (площа) ураження $S_{3}=1090 n^{2}$; число установок прицілу $n_{2}=3$; число установок кутоміра $n_{\phi}=6$; відстань між точками прицілювання по дальності (величина стрибка прицілу) $h_{x}=72 \mu ;$ по напрямку $h_{z}=32 \mu ; \quad N=150 c н$; $E_{\partial_{3}}=77 \mu ; \Gamma_{y} \times \Phi_{y}=150 \times 150 n^{2} ; E_{н 3}=42 u ; B_{\partial 3}=70 \mu$ $; B_{\text {бз }}=24 \mu ; \Delta n=0.56$.

Послідовно (див. рис. 2) отримуємо:

1) умовні розміри цілі по фронту $\Phi_{y}^{*} \approx 188 \mathrm{M}$ i глибині $\Gamma_{y}^{*} \approx 188$ м;

2) зведені середні помилки підготовки та розсіювання за дальністю стрільби 12 км для 152-мм СГ2C3

$$
\begin{aligned}
& E_{\partial 3}^{\prime}=\sqrt{E_{\partial 3}^{2}+0,038 \Gamma_{y}^{* 2}} \approx 85 \mu, \\
& E^{\prime}{ }_{\mu 3}=\sqrt{E_{H 3}^{2}+0,038 \Phi_{y}^{* 2}} \approx 56 \mu ;
\end{aligned}
$$

3) зону рівномірного розподілу точок падіння снарядів при числі установок прицілу $n_{2}=3$, числі установок кутоміра (по числу гармат) $n_{\phi}=6$, відстань між точками прицілювання $h_{x}=72 \mu$ по дальності і $h_{z}=32 м$ по напрямку, маємо

$$
\begin{gathered}
\Gamma_{\text {зрр }}=\sqrt{26,4 B_{\partial з}^{2}+\left(n_{2}^{2}-1\right) h_{x}^{2}}=413 \mu, \\
\Phi_{\text {зрр }}=\sqrt{26,4 B_{\text {бз }}^{2}+\left(n_{\phi}^{2}-1\right) h_{z}^{2}}=226 \mu ;
\end{gathered}
$$




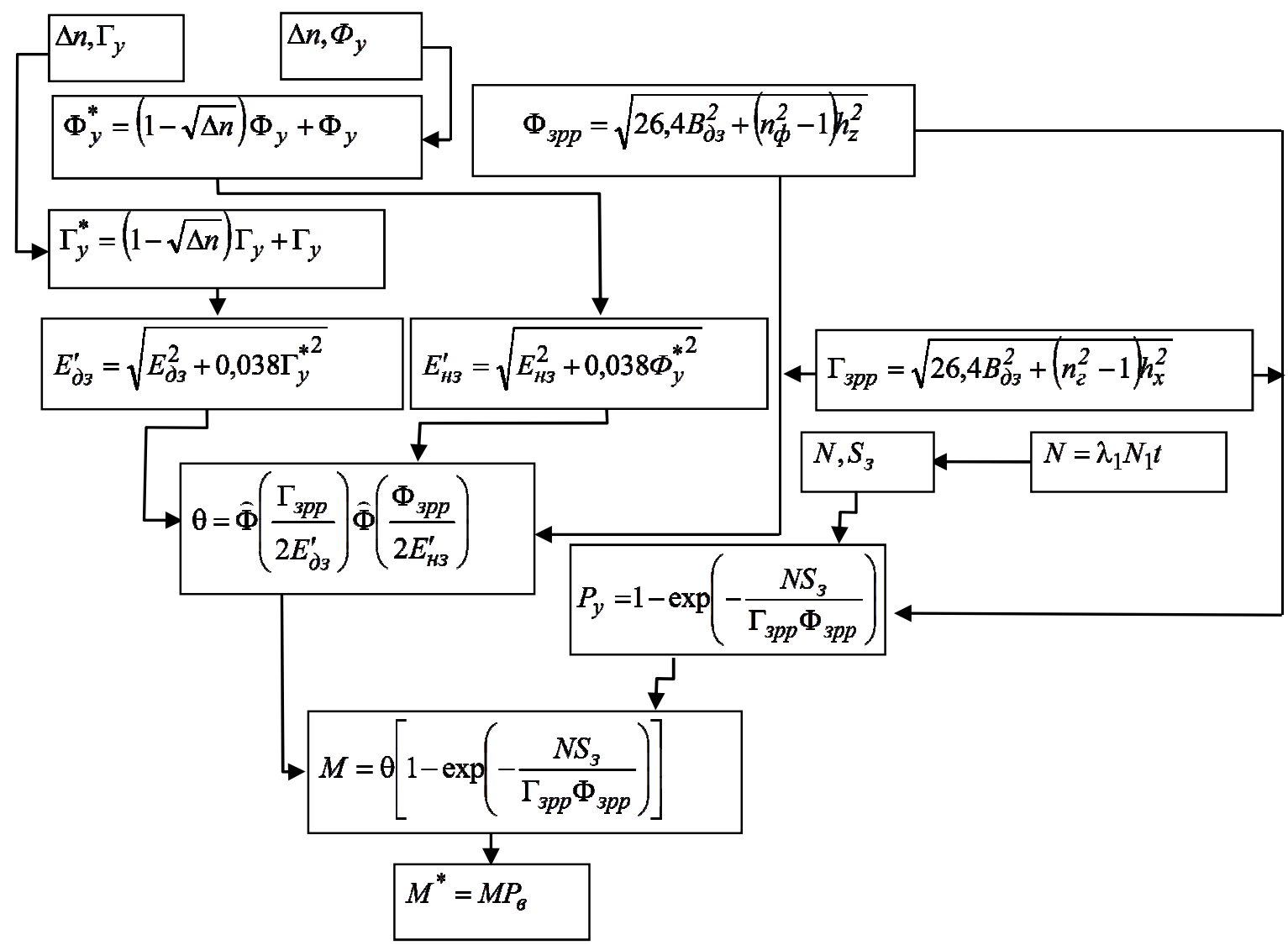

Рис. 2. Алгоритм розрахунку ступеня ураження цілей противника:

$n_{2}$ - число установок приџілу (число батарей); $n_{\phi}$ - число установок кутоміра (число гармат в батареї);

$h_{x}\left(h_{z}\right)$ - відстань між точками прицілювання по дальності (напрямку); $B_{\partial 3}\left(B_{\sigma_{3}}\right)-$ зведені серединні помилки розсіювання по дальності (напрямку); $\Gamma_{\text {зрр }}\left(\Phi_{\text {зрр }}\right)$-зведені серединні помилки розсіювання по дальності (напрямку);

$h$ - число виявлених гармат; $\Delta n$-частка (математичне сподівання) площі иілі, щэо накрита зоною ураження 6 залежності від числа виявлених гармат; $E_{\partial 3}^{\prime}\left(E_{н 3}^{\prime}\right)$ - зведені серединні помилки підготовки при стрільбі по груповій цілі за дальністю (напрямком); $\Phi_{y}^{*}\left(\Gamma_{y}^{*}\right)$-умовні розміри по фронту (глибині); $S_{3}-$ зведена зона ураження;

$\theta$ - імовірність накриття иілі областю розривів; $N$ - загальна витрата снарядів; $E_{\partial 3}\left(E_{н з}\right)-$ зведені серединні помилки підготовки по дальності (напрямку); $\Phi_{y}\left(\Gamma_{y}\right)$ - розміри ицілі по фронту (глибині)

4) шукану ймовірність $\theta[8]$ :

$$
\theta=\widehat{\Phi}\left(\frac{\Gamma_{\text {зрp }}}{2 E_{\partial 3}^{\prime}}\right) \cdot \widehat{\Phi}\left(\frac{\Phi_{\text {зрp }}}{2 E^{\prime}{ }_{\text {H3 }}}\right)=0,74 ;
$$

5) умовну ймовірність ураження за умови, що ціль накрита зоною рівномірного розсіювання, знайдемо за формулою

$$
P_{y}=1-e^{-\frac{N S_{3}}{\Gamma_{3 p p} \Phi_{3 p p}}} .
$$

Загальна витрата снарядів, згідно $з$ умовою задачі, на ураження цілі $N=150 \mathrm{cr}$, зведена зона ураження $S_{3}=1090 \mu^{2}$, тоді отримуємо

$$
P_{y}=1-e^{-\frac{150 \cdot 1090}{413 \cdot 226}}=1-e^{-1,75}=0,83 \text {; }
$$

6) повну ймовірність ураження цілі (хоча б одне влучення) знаходимо за формулою

$$
P(y \geq 1)=\theta \cdot\left(1-e^{-\frac{N S_{3}}{\Gamma_{3 p p} \Phi_{3 p p}}}\right)=0,74 \cdot 0,83=0,61 .
$$

Провівши аналогічний розрахунок для кожного елемента матриці (1), отримаємо наступні результати (табл. 1). 
Ймовірність ураження цілей в залежності від заданого засобу ураження

\begin{tabular}{|c|c|c|c|c|c|c|c|}
\hline Важливість & Цілі Засоби & $\begin{array}{c}\text { дивізіон } \\
\text { (2/3 БрАГ) }\end{array}$ & $\begin{array}{c}1 \text { батарея } \\
(2 / 3 \text { БрАГ) }\end{array}$ & $\begin{array}{c}2 \text { батарея } \\
(2 / 3 \text { БрАГ) }\end{array}$ & $\begin{array}{c}\text { дивізіон } \\
\text { (1/3 БрАГ) }\end{array}$ & $\begin{array}{c}1 \text { батарея } \\
(1 / 3 \text { БрАГ) }\end{array}$ & $\begin{array}{c}2 \text { батарея } \\
(1 / 3 \text { БрАГ) }\end{array}$ \\
\hline $\mathrm{A}_{1}=50$ & $\begin{array}{c}\text { А51 } \\
\text { (арт. батарея) }\end{array}$ & 0,32 & 0,13 & 0,21 & 0,25 & 0,1 & 0,19 \\
\hline $\mathrm{A}_{2}=30$ & 302 (КП) & 0,23 & 0,09 & 0,15 & 0,19 & 0,07 & 0,14 \\
\hline $\mathrm{A}_{3}=20$ & 301 (РЛС) & 0,63 & 0,35 & 0,54 & 0,61 & 0,31 & 0,48 \\
\hline $\mathrm{A}_{4}=0$ & 212 (АРК) & 0,41 & 0,17 & 0,21 & 0,36 & 0,15 & 0,20 \\
\hline $\mathrm{A}_{5}=0$ & 211 (Ж.С.) & 0,39 & 0,18 & 0,27 & 0,34 & 0,16 & 0,26 \\
\hline $\mathrm{A}_{6}=0$ & $\begin{array}{c}\text { M21 } \\
\text { (мін. батарея) }\end{array}$ & 0,54 & 0,27 & 0,37 & 0,48 & 0,21 & 0,37 \\
\hline
\end{tabular}

В даній таблиці кожний елемент показує ймовірність ураження відповідної цілі відповідним засобом.

Використовуючи розроблений алгоритм i результати табл. 1 (як вхідні дані), представимо отриманий розв'язок задачі у вигляді табл. 2

Таблиия 2

\begin{tabular}{|c|l|l|}
\hline $\begin{array}{c}\text { Номер } \\
\text { кроку }\end{array}$ & \multicolumn{1}{|c|}{ Засіб ураження } & Ціль \\
\hline 1 & Дивізіон (2/3 БрАГ) & А51 (арт. батарея) \\
\hline 2 & Дивізіон (2/3 БрАГ) & 301 (РЛС) \\
\hline 3 & Дивізіон (2/3 БрАГ) & А51 (арт. батарея) \\
\hline 4 & Дивізіон (1/3 БрАГ) & А51 (арт. батарея) \\
\hline 5 & Дивізіон (1/3 БрАГ) & 302 (ком. пункт) \\
\hline 6 & Дивізіон (1/3 БрАГ) & 302 (ком. пункт) \\
\hline
\end{tabular}

Як ми бачимо, всього по цілі А51 буде здійснено 3 вогневі нальоти, по цілі 302 - 2 вогневі нальоти і по цілі $301-1$ вогневий наліт, тобто кількість ударів по цілі тим більша, чим більша ㄲi важливість. При цьому логічно, що всі вогневі нальоти завдані дивізіоном (2/3 БрАГ), оскільки в даному випадку він має найбільшу вогневу силу. Також ми бачимо, що в першу чергу була атакована ціль А51, це пояснюється тим, що вона є найбільш небезпечною.

Отже, отримані результати повністю адекватні, це говорить про правильність побудованої математичної моделі.

Зазначимо, що цільова функція приймає значення $\Phi_{\text {опт. розв. }} \approx 59,1$, що реально відображає можливості засобів ураження (рис. 3 ).

Як видно, отримана функція є випуклою вгору, тобто для кожного кроку рішення задачі $\epsilon$ оптимальним.

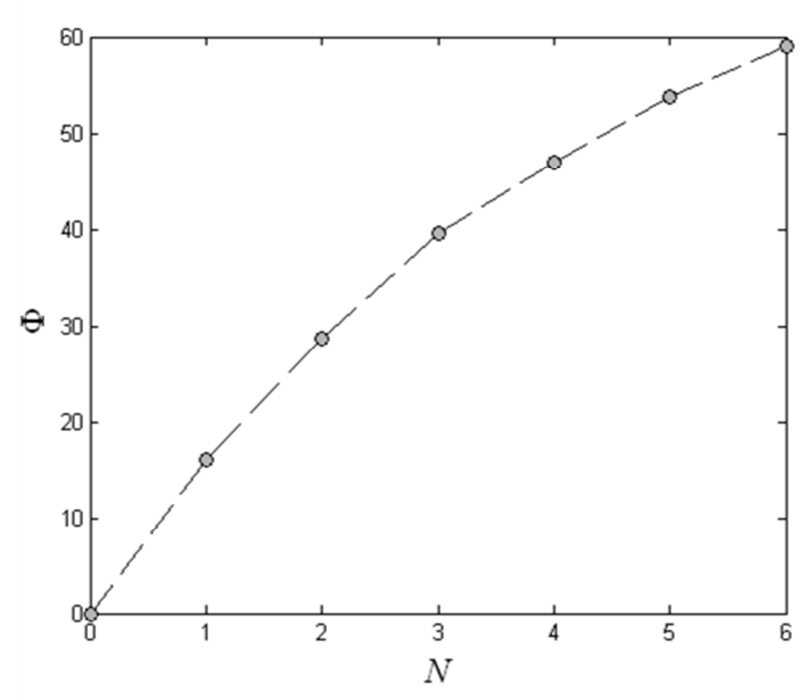

Рис. 3. Графік залежності значення цільової функції від номера кроку (удару засобу по цілі)

\section{Висновки}

У статті наведена математична модель, яка дає змогу розв'язати задачу, що описує процес бойових дій між двома протидіючими угрупованнями.

На основі методу максимального елемента було розроблено алгоритм розв'язку і відшукано оптимальний вектор розподілу засобів ураження по цілях, зокрема була вирішена практична задача, яка полягає в завданні найбільш важливим силам противника максимальних втрат за допомогою бойових засобів 2/3 і 1/3 БрАГ.

Розроблено алгоритм, за допомогою якого знаходиться математичне сподівання відносного числа уражених окремих цілей зі складу групової або ймовірність ураження цілі.

Проведено детальний аналіз запропонованих алгоритмів і показано, що вони дійсно є оптимальними на кожному кроці розрахунку цільової функції. 
Відмітимо, що розв'язана задача та отримані результати, дозволяють раціонально використовувати бойові угруповання в операціях і бойових діях, знаходити оптимальні варіанти їх використання, краще прогнозувати тактичну обстановку i приймати найбільш вірні рішення.

Перспективним напрямом подальших досліджень є знаходження математичної моделі оптимального розподілу засобів ураження по цілях противника, за умови нелінійного обмеження на її компоненти.

\section{Список літератури}

1. Основи теории управления войсками [Под редакиией Алтухова П.К.]. - М.: Воениздат, 1984. - 221 c.

2. Городнов В.П. Моделирование боевых действий частей, соединений, объединений войск ПВО / В.П. Городнов. Х.: АПО, 1987. -378 c.

3. Чуев Ю.В. Исследование операиий в военном деле / Ю.В. Чуев. - М.: Воениздат, 1970. - 256 c.

4. Кузнечов Ю.Н. Математическое программирование / Ю.Н. Кузнецов, В.И. Кузубов, А.Б. Волощенко. - М.: Высш. школа, 1980. - $300 \mathrm{c}$.

5. Гурин Л.С. Задачи и методь оптимального распределения ресурсов / Л.С. Гурин, Я.С. Дымарский, А.Д. Меркулов. - М.: Сов. радио, 1968. - 461 с.

6. Беллман Р. Динамическое программирование / Р. Беллман. - М.: Иностранная литература, 1960. - 400 c.
7. Аверьянов А. И. и др. Управление в системах РАВ, ч.1 - Л.: ВАA, 1980. - $368 c$.

8. Абчук В. А. и др. Справочник по исследованию операчий. - М.: Воениздат, 1979. - 369 c.

9. Юдин Д.Б. Задачи и методы линейного программирования, изд. 2-е / Д.Б. Юдин, Е.Г. Гольштейн. - М.: Сов. радио, 1964. . - $254 \mathrm{c}$.

10. Арис Р. Дискретное динамическое программирование / Р. Арис. - М.: Мир, 1969. - 171 c.

11. Вентиель Е.С. Элементы динамического програмиирования / Е.С. Вентиель. - М.: Наука, 1964. - 176 с.

12. Лиман Ф.М. Вища математика / Ф.М. Лиман, В.Ф. Власенко і ін. - С.: Унів. кн., 2006. - 614 с.

13. Вентчель Е.С. Исследование операиий / Е.С. Вентиель. М.: Сов. радио, 1972. -552 c.

14. Барковский А.Ф. Основы оценки эффективности и выработки рекомендаций по поражению целей огнем артиллерии / А.Ф. Барковский. - СПб.: ВАУ, 2000. - 309 с.

15. Правила стрільби і управління вогнем наземної артилерії: група, дивізіон, батарея, взвод, гармата / В.М. Рябоконь, П.Й. Руденко, П.В. Полениия, О.В. Смірнов. К.: Міністерство оборони, 2008. - 232 c.

Рецензент: д.т.н, проф. Л.І. Сопільник, Академія сухопутних військ імені гетьмана Петра Сагайдачного, Львів.

\title{
Математическая модель оптимального распределения средств поражения
}

\author{
В.И. Грабчак, В.Н. Супрун, Ю.С. Бистрик
}

В статье разработана математическая модель оптимального распределения средств поражения по иелям противника. Обоснован метод нахождения оптимального решения задачи двустороннего боя между противодействующими неоднородными группировками на основании метода максимального элемента (градиентный метод), приведен алгоритм, с помощью которого рассчитаны показатели эффективности поражения целей противника. Рассмотрен практический пример функиионирования модели оптимального распределения средств поражения.

Ключевые слова: математическая модель, оптимальные методы управления, метод максимального элемента, показатели эффективности поражения.

\section{Mathematical model of engagement systems optimum allocation}

\author{
V. Hrabchak, V. Suprun, Y. Bystryk
}

The article presents mathematical model of optimum allocation of enemy targets engagement systems. The method for finding optimum solution of the task of two-side combat between opposing heterogenic formations based on the universal element method (gradient method) is grounded; algorithm using which effectiveness parameters of enemy target engagement were calculated is given. Application example of model functioning of engagement means optimum allocation is considered.

Key words: mathematical model, optimum command means, universal element method, effectiveness factors of engagement. 